\title{
Inter-cohort growth patterns of pharaoh cuttlefish Sepia pharaonis (Sepioidea: Sepiidae) in Eastern Arabian Sea
}

\author{
Geetha Sasikumar ${ }^{*}$, K.S. Mohamed ${ }^{2}$ \& U.S. Bhat ${ }^{1}$ \\ 1. Central Marine Fisheries Research Institute, Research Centre, Mangalore, PB 244, Karnataka 575001, India; geetha \\ sasikumar@yahoo.com, umas.bhat@rediffmail.com \\ 2. Central Marine Fisheries Research Institute, Kochi, PB 1603, Kerala 682018, India; ksmohamed@vsnl.com \\ * Corresponding author
}

Received 17-I-2012. C Corrected 30-VII-2012. Accepted 28-VIII-2012.

\begin{abstract}
Sepia pharaonis is an important commercial species endemic to the tropical Indo-Pacific region. Despite its commercial significance, only few information on natural populations is available. This study was aimed to describe the aspects of size-composition, length-weight relationship, catch rates, seasonal recruitment and inter-cohort growth patterns of $S$. pharaonis population (Clade C), distributed along the Eastern Arabian Sea (South-West coast of India). For this, the Dorsal Mantle Length (DML) and weight of cuttlefishes was obtained from commercial trawl catches, from April 2002 to October 2006. Data was analyzed by normal length-weight methods such as von Bertalanffy. A total of 12454 cuttlefishes, ranging in length from four to $41 \mathrm{~cm}$ were analyzed. Size-composition patterns discriminated two pulses in recruitment to the fishery, discernible by a decrease in the monthly mean size of the population. The DMLs of the two seasonal cohorts were subjected to modalprogression analysis using the Bhattacharya's method for the estimation of growth. The estimated parameters L $\infty$ and $\mathrm{K}$ in von Bertalanffy Growth Function (VBGF) were used to model growth curves in length for the cohorts. The first cohort, (post-monsoon cohort) which supports the major fishery, was composed of mediumsized, fast growing individuals, whereas the second cohort (pre-monsoon cohort), comprised of slow growing and large-sized individuals. There were differential growth characteristics between the sexes and the life span was estimated at less than 2.3years for males and 2.1years for females. Negative allometric growth in weight (W) with length $(\mathrm{L})$ was observed for males $\left(\mathrm{W}=0.33069 . \mathrm{L}^{2.5389}\right)$ and females $\left(\mathrm{W}=0.32542 . \mathrm{L}^{2.6057}\right)$. The females were heavier compared to males at any given mantle length, and the males were found to attain larger ultimate lengths. The major fishing season for cuttlefish was from May to November, when higher monthly catch rates of $1.67-13.02 \mathrm{~kg} / \mathrm{h}$ were observed in comparison with $0.03-0.85 \mathrm{~kg} / \mathrm{h}$ in December-April. Seasonal catch rates indicated a migratory life cycle of $S$. pharaonis between offshore and inshore coastal zones. Rev. Biol. Trop. 61 (1): 1-14. Epub 2013 March 01.
\end{abstract}

Key words: cuttlefish, Sepia pharaonis, growth, length-weight relationship, age, Eastern Arabian Sea.

Cephalopod resources have gained topical importance internationally as a commercial fishery only in the recent decades (Boyle 1990). The pharaoh cuttlefish Sepia pharaonis Ehrenberg, 1831, is one of the most important species exploited along the Eastern Arabian Sea. Being a neritic demersal species endemic to the tropical waters of the Indo-Pacific region (Including Red Sea, Arabian Sea, Andaman Sea to South China Sea, East China Sea, Japan, Eastern Indonesia to Southern Australia including Gulf of Carpentaria) commercial catches of $S$. pharaonis are reported from coastal waters up to a depth of $130 \mathrm{~m}$. The species is known to undertake seasonal migrations between the continental shelf waters and shallow coastal waters for feeding and spawning (Reid et al. 2005). The maximum sizes reported for the species is $420 \mathrm{~mm}$. Phylogenetic analyses of $S$. pharaonis in its distributional range revealed five distinct clades within the $S$. pharaonis species complex (Anderson et al. 2007). Accordingly, the Clade 
C of the $S$. pharaonis population confined to Arabian Sea, Bay of Bengal and Andaman Sea (Andaman Sea coast of Thailand) is exploited in the Eastern Arabian Sea.

In spite of the $S$. pharaonis wide distribution along the Eastern Arabian Sea, the biology of this resource has not been studied comprehensively and the information is scarce on its growth patterns. Some aspects of $S$. pharaonis fishery have been addressed from Australia (Dunning et al. 1994), Yemen (Sanders 1979, Aoyama \& Nguyen 1989), Thailand (Chotiyaputta 1993) Philippines (Watanuki et al. 1993) and Egypt (Gabr et al. 1999). S. pharaonis is also a highly promising species for aquaculture (Nabhitabhata 1995) and is extensively studied under controlled laboratory conditions (Nabhitabhata \& Nilaphat 1999, Minton et al. 2001, Anil et al. 2005, Barord et al. 2010).

Along the Indian coast, cephalopods constitute a fishery of commercial significance, where the production exhibited a quantum leap in the past few decades. The production from fishery in India reached 111 534t from 94t in four decades, at a significantly greater rate of increase than the finfish group (Meiyappan \& Mohamed 2003). Catches of S. pharaonis in the State of Karnataka, along the Eastern Arabian Sea, have increased substantially from 3t-1980 to 6 703t-2006, raising concern about the species and consideration for development of a resource management plan. The commercial trawl fleet of Karnataka consists of two types of fleets, the single-day fleet (SDF) comprising of smaller trawlers ( $<9 \mathrm{~m}$ overall length) and the multi-day fleet (MDF) of medium sized ( $>9 \mathrm{~m}$ overall length; majority $11-17.1 \mathrm{~m}$ overall length) trawlers. SDF undertake daily fishing operations in the inshore waters up to $25 \mathrm{~m}$ depth zone whereas, MDF carry out longer voyages and operate beyond $25 \mathrm{~m}$. The average gross registered tonnage of the MDF vessels is $27 \mathrm{t}$ with engine power ranging from 80 to 120HP (Zacharia et al. 1996). Cuttlefishes are targeted by MDF, catching more than $98 \%$ of the resource. Mechanized fishing, including trawling is closed for a period of 45 days (June 15 to July 30 ) as a regulatory measure.
The commercial fishing ground extends from $10^{\circ} 30^{\prime} 00^{\prime \prime} \mathrm{N}-75^{\circ} 45^{\prime} 00^{\prime \prime} \mathrm{E}$ off Ponnani in South to $17^{\circ} 20^{\prime} 00^{\prime \prime} \mathrm{N}-72^{\circ} 42^{\prime} 00^{\prime \prime} \mathrm{E}$ off Ratnagiri in the North (GPS data). This included the area lying in the depth zone of the Bassasde-Pedro Bank/Padua Bank (130.07'00.57' N $\left.72^{\circ} 25^{\prime} 00.15^{\prime \prime} \mathrm{E}\right)$ and around the Netrani Islands, $\left(14^{\circ} 08^{\prime} 00^{\prime \prime} \mathrm{N}-74^{\circ} 47^{\prime} 00^{\prime} \mathrm{E}\right)$ which are known for their abundance in cephalopods, yielding higher catch rates (Nair et al. 1992). The depth of operation of MDF increased over the years from 50m-1986 (Rao 1998) to 70m-1991 (Mohamed 1996). In 1995, the trawling depth increased beyond $70 \mathrm{~m}$ when cephalopods were targeted reaching 100m (Zacharia et al. 1996) and continued to increase further, reaching depths of $150 \mathrm{~m}$ since 2001 (Dineshbabu et al. 2001). This neritic demersal cuttlefish species is targeted almost throughout the year, excluding the mechanized fishing ban period, by bottom trawl (22 to $24 \mathrm{~mm}$ cod end mesh size) in the commercial trawling ground of MDF.

Earlier studies reported from India on this resource are by Silas et al. (1985), Philip \& Ali (1989), Nair et al. (1993) and Abdussamad et al. (2004) based on the S. pharaonis from the Southern coastal waters of India. However, little has been reported on the growth and stock assessment of $S$. pharaonis in the region. The present study therefore describes the lengthweight relationship, catch rates, seasonal recruitment and inter-cohort growth patterns of S. pharaonis from this tropical monsoon region based on commercial catches.

\section{MATERIALS AND METHODS}

Study area and oceanography: Arabian Sea experiences seasonal reversal in current patterns, changing with the monsoon winds. With the onset of the South-West monsoon (June-September), the surface waters move away from the coast under the influence of the SW winds and are replaced by colder, nutrient-rich and often oxygen depleted waters from the subsurface (Ekman pumping/ transport) (Madhupratap 2001). The upwelling lasts throughout the SW monsoon period until 
September-October. Coastal currents during this period are South-flowing (Johannessen et al. 1981). From November, the surface circulation is dominated by a weak westward, countermonsoon flow when, the coastal currents flow Northwards associated with the influx of low salinity water from the South.

The SST in the study area shows a primary peak during April-May and a secondary peak during October-November, with lowest temperatures during July-September (Krishnakumar \& Bhat 2008).

Sampling: A total of 12454 individuals of Sepia pharaonis were examined, ranging in length from four to $41 \mathrm{~cm}$ DML. S. pharaonis samples were collected from commercial MDF trawl catches during April 2002-October 2006. The data were collected weekly, recording the catch and effort from the major fishing harbours at Mangalore and Malpe (Fig. 1). The cuttlefishes were weighed to the nearest $0.1 \mathrm{~g}$ and measured to the nearest $0.1 \mathrm{~cm}$ in dorsal mantle length (DML-measured as the distance from the base of the spine to the anterior tip of the mantle) and sexed by macroscopic examination of the gonads. The length frequencies of cuttlefish in each sample were regrouped at an interval of $10 \mathrm{~mm}$ in DML, projected to the day's catches and used for representing the length-frequency of the estimated catch in the trawl landings during each sampling period, as outlined by Mohamed \& Rao (1997). These length frequencies were weighted to the estimated S. pharaonis catch of Karnataka State. The data was analysed seasonally (Pre-monsoon- February to May; monsoon-June to September; Post-monsoon-October to January).

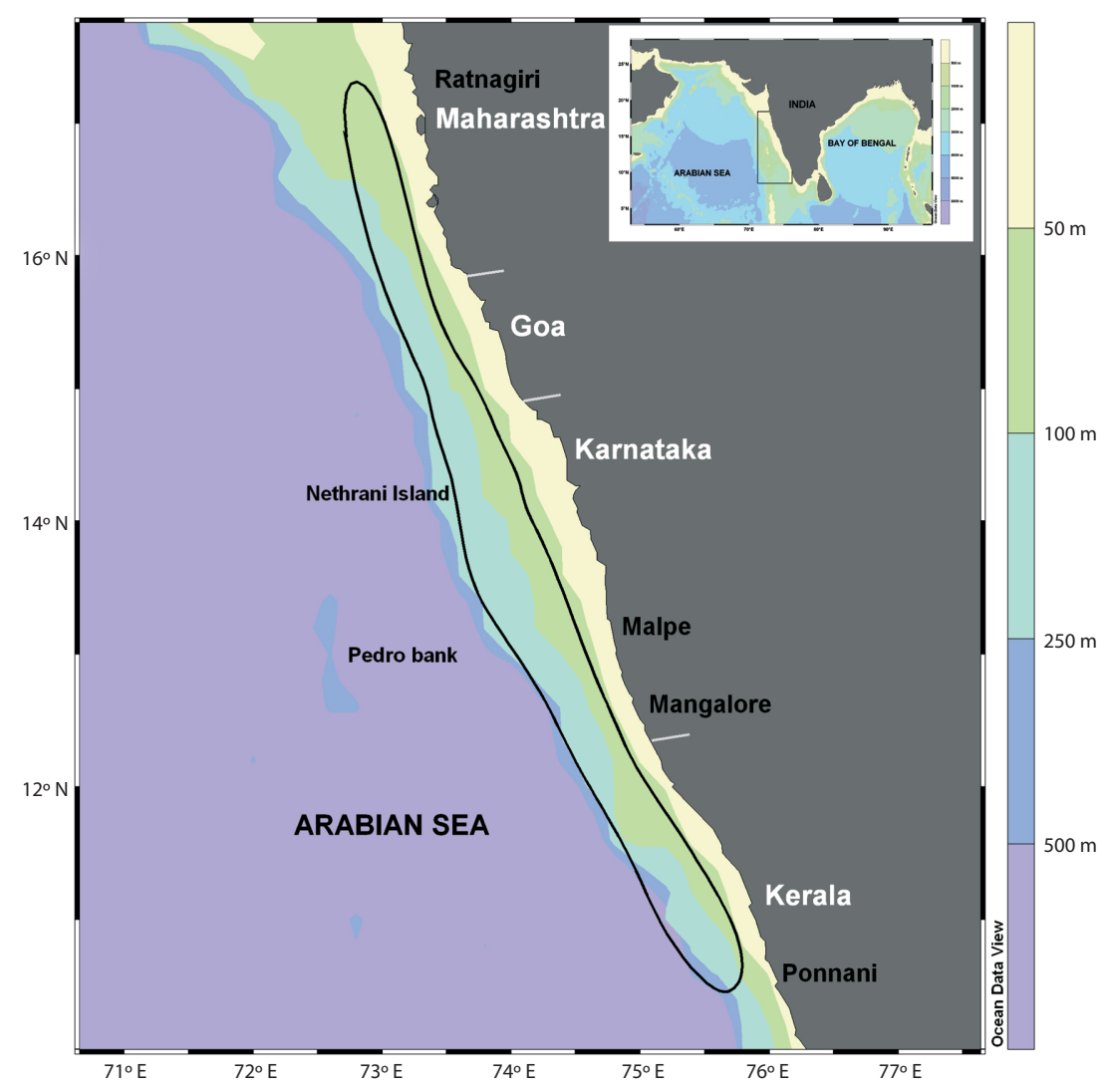

Fig. 1. The study area showing the extent of the trawling ground (boxed area). 
The catch and effort were estimated following a multi-stage random sampling design (Srinath et al. 2005). Briefly, the method involves observations of catch $(\mathrm{kg} / \mathrm{trawl})$ and effort (h) for a period of $12 \mathrm{~h}$ in a "center-day" comprising of two consecutive calendar days. This cuttlefish daily catch and effort from at least $10 \%$ of the vessels were multiplied with the number of vessels on the observation day to arrive at the daily estimate. To obtain the monthly estimates, the daily data were pooled and multiplied by the number of fishing days in a month. The catch-per-unit-effort (CPUE), in terms of catch $(\mathrm{kg})$ per trawling hours was used as an index of abundance.

Length-weight relationships were established for females and males separately applying the linear form of the equation, $\mathrm{W}=\mathrm{a}$. $\mathrm{L}^{\mathrm{b}}$. The parameters $a$ and $b$ were estimated by least square linear regression on the logtransformed length $\left(\log _{\mathrm{e}} \mathrm{x}\right)$ and weight $\left(\log _{\mathrm{e}} \mathrm{y}\right)$ data: $\ln ($ total wet weight $)=b \ln (\mathrm{DML})+\ln$ $a$. The coefficient of determination $\left(r^{2}\right)$ was used as an indicator of the appropriateness of the model. The regression functions of males and females were compared using the analysis of covariance (ANCOVA). $F$-test was used for determining significant differences $(p=0.01)$ in the weight-at-length relationship between the sexes and to test the significant differences between the intercepts (Snedecor \& Cochran 1967). Further, in order to validate whether the values of the slope $(b)$ obtained in the linear regression were significantly different from the isometric value $(b=3)$, a t-test was used following the equation (Sokal \& Rohlf 1995): $\mathrm{t}_{\mathrm{s}}=(\mathrm{b}-$ $3) / s_{b}$ where, $t_{s}=t$-test value, $b=$ slope and $s_{b}=$ standard error of the slope (b). Subsequently, the value obtained was compared with the table critical value to determine whether growth is isometric or allometric.

Techniques based on length frequency analysis, broadly suggested for tropical fish growth evaluations (Sparre \& Venema 1998) were applied to describe the growth parameters of $S$. pharaonis, from the study area. Lengthfrequency data collected was analysed to discern differences in cohorts within the fishery annually. Since, monthly frequencies within the commercial fishery showed evidence of cohort dominance when compared graphically using histograms, they were subjected to modalprogression analysis to identify differences in growth. The separation of normal distributions from the composite size distributions was performed using the Bhattacharya's method using the routine in FAO-ICLARM Fisheries Assessment Tools (FiSAT) software (Gayanilo et al. 1995) preceded by a correction for the gear selectivity on the length frequency of each size present in the sample (Sparre \& Venema 1998). For this purpose, a preliminary estimate of $\mathrm{L}_{\infty}$ and $\mathrm{K}$ were used to derive probabilities of capture by length class. The probabilities of capture were used to correct the length distribution data to account for incomplete selection and recruitment. The mean lengths of each cohort component were linked by modal progression analysis to represent the growth pattern. The final estimates of $\mathrm{L}_{\infty}$ and $\mathrm{K}$ were obtained by Gulland \& Holt plot (Sparre \& Venema 1998) by plotting the growth rate against the mean length derived from modal progression analysis in the time series of length frequency data. Estimates of growth parameters obtained were used for calculating the length of the cohorts for different arbitrary ages by fitting the von Bertalanffy Growth Function (VBGF) model, following the equation: $\mathrm{L}_{\mathrm{t}}=\mathrm{L}_{\infty}\left(1-\mathrm{e}^{[\mathrm{K}(\mathrm{t}-\mathrm{t}) \mathrm{l})]}\right.$ where, $\mathrm{L}_{\infty}$ is the asymptotic length, $\mathrm{K}$ is the von Bertalanffy growth coefficient synonymous to the rate at which $\mathrm{L}_{\infty}$ is attained (per year), $\mathrm{L}_{t}$ length at age $t, t_{0}$ is the length for the hypothetical age at zero length. The growth performance index, $\varphi=\log _{10} \mathrm{~K}+2 \log _{10} \mathrm{~L}_{\infty}$ (Pauly \& Munro 1984), was computed using the $\mathrm{L}_{\infty}$ and $\mathrm{K}$ values for comparison of growth performance of $S$. pharaonis from the study area with those from other areas.

Peak spawning of $S$. pharaonis is reported in October/November $\left(\mathrm{Lm}_{50 \%}-214 \mathrm{~mm}\right)$ and in February/March $\left(\mathrm{Lm}_{50 \%}-121 \mathrm{~mm}\right)$ (Sasikumar 2011).

The length-weight relationship and growth parameters results of $S$. pharaonis were 
compared with those reported along its distributional range in tables 1 and 2 respectively.

\section{RESULTS}

Catch rates: Subsequent to the fishing ban (June-July) in the monsoon season, the commercial fishing operations in the region commences from August. The major fishing season of cuttlefish is during May-November, when monthly catches $(1.67-13.02 \mathrm{~kg} / \mathrm{h})$ are several times higher than those in DecemberApril $(0.03-0.85 \mathrm{~kg} / \mathrm{h})$. In the post-monsoon season, higher catch rates $(4.16-13.02 \mathrm{~kg} / \mathrm{h})$ in cuttlefish landings occurred in the beginning of the fishing season, from August to October

TABLE 1

Length-weight relationship (W.aL ${ }^{\mathrm{b}}$ ) of $S$. pharaonis by study area

\begin{tabular}{|c|c|c|c|c|c|c|c|}
\hline Study area & Sex & Size range & $\mathrm{N}$ & $\mathrm{a}$ & b & $r^{2}$ & References \\
\hline \multirow[t]{3}{*}{ Karnataka, SW India } & Males & $5.5-37 \mathrm{~cm}$ & 453 & 0.33069 & 2.53897 & 0.98 & Present study \\
\hline & Females & $5.1-35 \mathrm{~cm}$ & 457 & 0.32542 & 2.60573 & 0.98 & \\
\hline & Population & $5.1-37 \mathrm{~cm}$ & 910 & 0.32507 & 2.55543 & 0.98 & \\
\hline \multirow[t]{2}{*}{ Vizhinjam, South India } & Males & $130-334 \mathrm{~mm}$ & & 0.000988 & 2.5058 & & Silas et al. (1985) \\
\hline & Females & $150-320 \mathrm{~mm}$ & & 0.000726 & 2.5478 & & \\
\hline \multirow[t]{2}{*}{ SE India } & Males & $90-150 \mathrm{~mm}$ & & 0.000609 & 2.5997 & & Nair et al. (1993) \\
\hline & Females & $90-170 \mathrm{~mm}$ & & 0.000560 & 2.6286 & & \\
\hline Gulf of Aden & Population & $8-43 \mathrm{~cm}$ & & 0.000563 & 2.693 & & $\begin{array}{c}\text { Aoyama \& } \\
\text { Nguyen (1989) }\end{array}$ \\
\hline \multirow[t]{2}{*}{$\begin{array}{l}\text { Gulf of Carpentaria, } \\
\text { Australia }\end{array}$} & Males & $34-173 \mathrm{~mm}$ & $327(\mathrm{M}+\mathrm{F})$ & 0.00015 & 2.89 & & $\begin{array}{l}\text { Dunning et } \\
\text { al.(1994) }\end{array}$ \\
\hline & Females & $28-192 \mathrm{~mm}$ & & 0.00029 & 2.76 & & \\
\hline \multirow[t]{2}{*}{ Suez Canal } & Males & $1-24 \mathrm{~cm}$ & 723 & 0.28 & 2.60 & 0.99 & Gabr et al. (1999) \\
\hline & Females & $1-24 \mathrm{~cm}$ & 966 & 0.27 & 2.65 & 0.99 & \\
\hline
\end{tabular}

$\mathrm{N}$-sample size; L-DML in cm; W- total weight in $\mathrm{g}$.

TABLE 2

Growth parameters of $S$. pharaonis by study area

\begin{tabular}{|c|c|c|c|c|c|c|c|}
\hline Region & & $\mathrm{L}_{\infty}(\mathrm{cm})$ & K(/year) & $\mathrm{t}_{0}$ (years) & $\varphi$ & $\mathrm{L}_{\max }(\mathrm{cm})$ & Reference \\
\hline Karnataka, SW coast, & Males & & & & & & \\
\hline \multirow[t]{5}{*}{ India Arabian Sea } & Post-monsoon cohort & 39 & 1.55 & -0.0493 & 3.4 & & Present study \\
\hline & Pre-monsoon cohort & 43 & 1.04 & -0.0814 & 3.3 & 41.0 & \\
\hline & Females & & & & & & \\
\hline & Post-monsoon cohort & 31 & 1.58 & -0.0510 & 3.2 & & \\
\hline & Pre-monsoon cohort & 37 & 1.02 & -0.0868 & 3.1 & 35.5 & \\
\hline Wadge Bank, India & Population & 37 & 0.5 & & & 37.0 & $\begin{array}{l}\text { Philip \& Ali } \\
\text { (1989) }\end{array}$ \\
\hline \multirow{2}{*}{$\begin{array}{l}\text { West coast, } \\
\text { India Arabian Sea }\end{array}$} & Males & 32.0 & 0.72 & & 2.9 & 33.4 & Nair et al. (1993) \\
\hline & Females & 29.6 & 0.82 & & 2.9 & 32.0 & \\
\hline \multirow{2}{*}{$\begin{array}{l}\text { East coast, India } \\
\text { Bay of Bengal }\end{array}$} & Males & 27.0 & 0.94 & & 2.8 & 26.5 & Nair et al. (1993) \\
\hline & Females & 23.0 & 1.0 & & 2.7 & 24.5 & \\
\hline $\begin{array}{l}\text { Kakinada, India } \\
\text { Bay of Bengal }\end{array}$ & Population & 31.9 & 0.92 & 0.0314 & 3.0 & 24.0 & $\begin{array}{l}\text { Abdusammad } \\
\text { et al. }(2004)\end{array}$ \\
\hline Gulf of Aden & Population & 40 & 1 & 0.072 & 3.2 & 43 & Sanders (1979) \\
\hline
\end{tabular}


(Fig. 2). The catch rates showed that cuttlefish became progressively less abundant from December onwards.

Length-weight relationships: Lengthweight relationships calculated for males and females $S$. pharaonis are presented in figure 3. The $b$ values for both sets of data were below three indicating negative $(b<3)$ allometric growth of weight with length for males, females and for the sexes combined ( $b$ significantly different from three, $t$-test, $\left.t>t_{0.01}\right)$. ANCOVA also showed significant differences between sexes for slope, $\left(\mathrm{F}=8.83>\mathrm{F}_{1907}=6.66 ; \mathrm{p}<0.01\right)$ and for the intercept $\left(\mathrm{F}=34.47>\mathrm{F}_{1908}=6.66 ; \mathrm{p}<0.01\right)$.

Size distribution: The monthly size distribution of $S$. pharaonis followed an identical intra-annual pattern. The DML of $S$. pharaonis in the commercial fishery ranged from four to $41 \mathrm{~cm}$ with size groups $12-25 \mathrm{~cm}$ dominating the catch. The fishery during the early monsoon (June) months, late monsoon (September) and early post-monsoon (October to December) was supported by larger size groups of $13-30 \mathrm{~cm}$, whereas, in late post-monsoon and pre-monsoon it was supported by $11-21 \mathrm{~cm}$ sized cuttlefish (Fig. 4). Results of the analysis of the seasonal size structure indicated that the catches were dominated by medium sized cuttlefish until September while, larger sized individuals were less abundant. Smaller size group in the range of $4-8 \mathrm{~cm}$ was represented

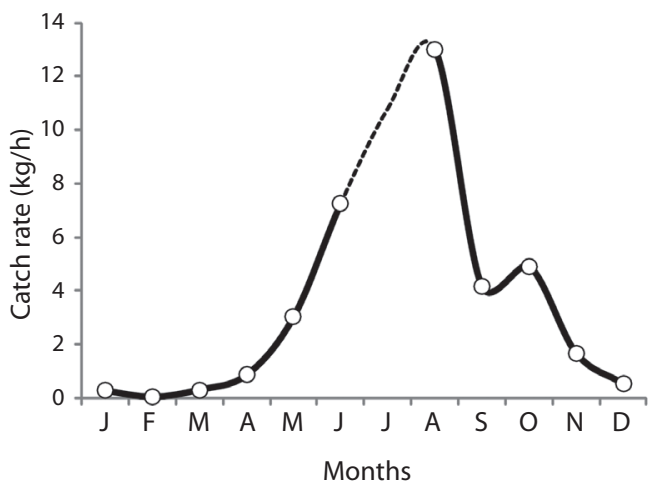

Fig. 2. Variations in catch rates of $S$. pharaonis in trawl landings. from January to June. Monthly length distribution of males and females showed a bimodal distribution from October to March, with larger

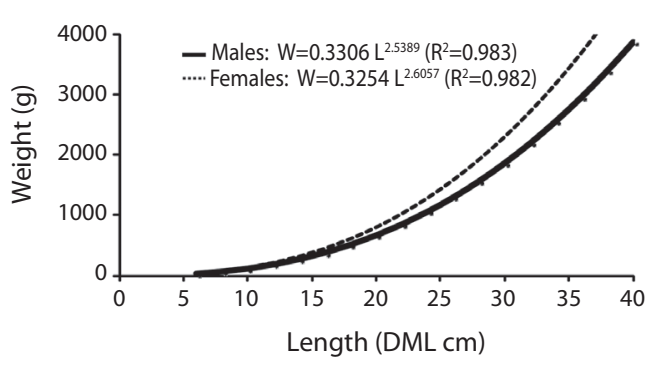

Fig. 3. Length-weight relationships fitted for $S$. pharaonis males and females.

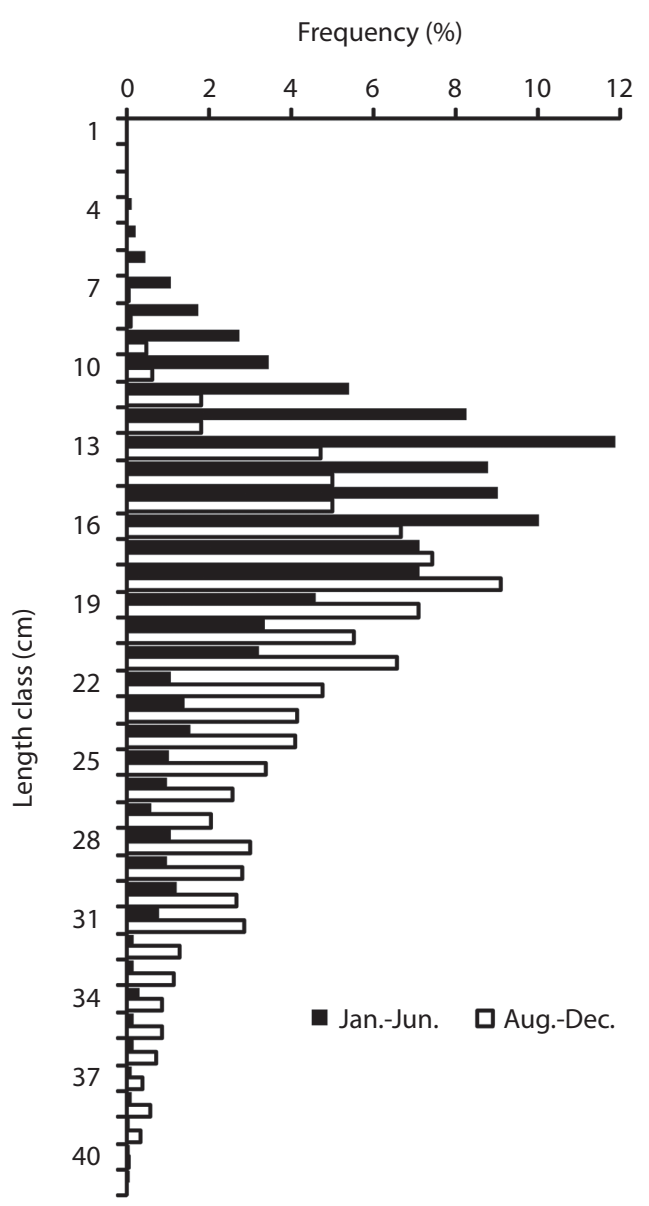

Fig. 4. Mantle length frequency distribution of S. pharaonis samples caught in commercial trawl during January-June and August-December periods. 
size groups evident during the post-monsoon months (Fig. 5). In April a unimodal distribution was evident with progression of the mode through December.

Analysis of the seasonal trends in mean length indicated that the monthly mean sizes of males were higher than the females throughout the fishery. The mean length of males was $19.6 \mathrm{~cm}(\mathrm{SD}=4.9)$ and female was $18.1 \mathrm{~cm}$ $(\mathrm{SD}=4.0)$. The mean size of females was greater from October to January, whereas smaller individuals were represented in the fishery from February to April (Fig. 6). Females were less numerous than males among the larger individuals above size group $27 \mathrm{~cm}$ and were not present above size group $35 \mathrm{~cm}$.

The mean size of the cuttlefish population, in the commercial landings progressed from $16 \mathrm{~cm}$ in May/June to $22 \mathrm{~cm}$ in October subsequently attaining $27 \mathrm{~cm}$ by November/ December. Recruitment was apparent with the entry of smaller sized cuttlefish in January and in May/June, discernible by a decrease in the mean size of the population. In January, though the mean size declined to $23 \mathrm{~cm}$, it was above the annual mean size $(18.8 \mathrm{~cm})$ of the population. It was observed from the length frequency distribution that recruitment to the fishery occurs in two spells with a major one in May/ June before the onset of monsoon and subsequently in January/February. The proportion of smaller individuals in the fishery is above $50 \%$ in January and in May/June, consequent to the recruitments. Hence, two distinct age groups or cohorts were apparent in the population.

Growth parameters: Two cohorts were identified, the first cohort that recruits to the fishery in January, which originate from a more extended spawning period from October/ November (post-monsoon spawning) and the second cohort that originated from a second spawning spell in February/March (pre-monsoon spawning).

The separation of modes from the size distributions of females using Bhattacharya method and fitting of the Gulland \& Holt plots resulted in higher estimates of curvature parameter
$\mathrm{K}, 1.579 \pm 0.22 /$ year for an $\mathrm{L}_{\infty}$ of $31 \pm 1.42 \mathrm{~cm}$ for the post-monsoon cohort and lower estimates of $\mathrm{K}(1.067 \pm 0.31$ /year $)$ and higher $\mathrm{L}_{\infty}$ $(37 \pm 3.81 \mathrm{~cm})$ for the pre-monsoon cohort (Fig. 7). In males, the post-monsoon cohort showed lower estimates of $\mathrm{L}_{\infty}(39 \pm 3.26 \mathrm{~cm})$ and higher estimates of $\mathrm{K}(1.551 \pm 0.32 /$ year $)$ whereas, for the pre-monsoon cohort higher estimates of $\mathrm{L}_{\infty}$ $(43 \pm 3.43 \mathrm{~cm})$ and lower K $(1.042 \pm 0.26 /$ year $)$ were obtained. The estimated parameters $\mathrm{L}_{\infty}$ and $\mathrm{K}$ in VBGF were used to model growth curves in length for males and females (Fig. 8). Growth models fitted were:

Post-monsoon cohort

Males: $\mathrm{L}_{\mathrm{t}}=39\left(1-\mathrm{e}^{[1.551(\mathrm{t}+0.0493)]}\right)$

Females: $L_{t}=31\left(1-e^{[1.579(t+0.0510)]}\right)$

Pre-monsoon cohort

Males: $\mathrm{L}_{\mathrm{t}}=43\left(1-\mathrm{e}^{[1.042(\mathrm{t}+0.0814)]}\right)$

Females: $\mathrm{L}_{\mathrm{t}}=37\left(1-\mathrm{e}^{[1.067(\mathrm{t}+0.0827)]}\right)$

The $t_{\max }$, the maximum observed age in the fishery (years), of female $S$. pharaonis was calculated as 2.1 for post-monsoon cohort and 2.6years for pre-monsoon cohort and correspondingly 2.3 and 2.8years for male. Modal analysis of the length frequency distribution indicated that the commercial trawl fishery was mostly supported by $0+$ year group dominated by the post-monsoon cohort (Fig. 5). Individuals in the size classes less than $8 \mathrm{~cm}$ corresponding to the juveniles were represented occasionally in the fishery. The phi-prime index was estimated as 3.3-3.4 for males and 3.1-3.2 for females.

\section{DISCUSSION}

Information on the size-composition of the fishery is critical in establishing management measures aimed at sustainable exploitation of the resources. Size structure of $S$. pharaonis observed reflects the length distribution of the catch over the recent past, representing almost all size categories including juveniles. The $\mathrm{L}_{\text {max }}$ observed in the catches ( $41 \mathrm{~cm}$ DML) was higher than that reported elsewhere in Indian waters (Silas et al. 1985, Nair et al. 1993), 
, Male a Female

2.

\% $\left.\begin{array}{r}10 \\ 10 \\ 5 \\ 0\end{array}\right]$

15 - April

$\%$

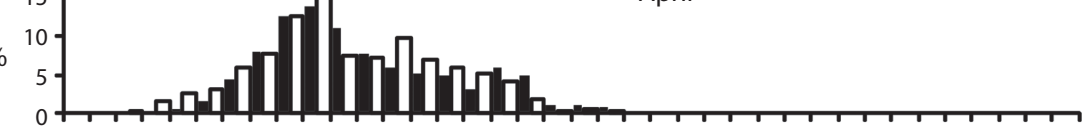

207 May

June

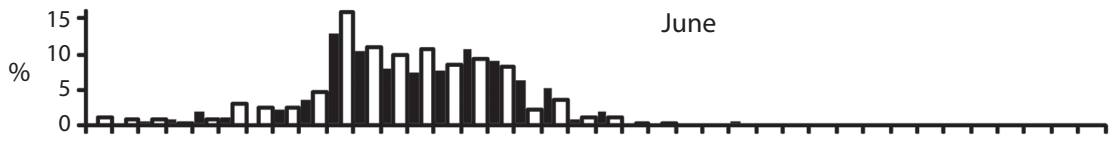

$15]$ August


Fig. 5. Mantle length frequency distribution of S. pharaonis samples caught in commercial trawl in 2005. 


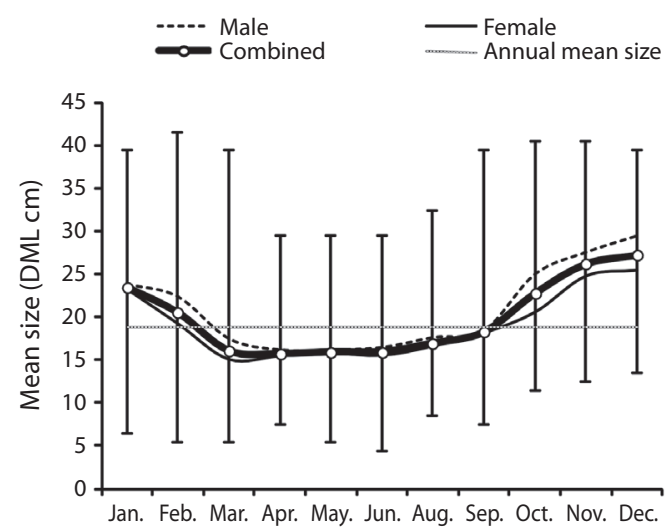

Fig. 6. Seasonal trends in mean size of $S$. pharaonis with deviations from annual mean size. Vertical lines denote monthly length ranges.

which can be attributed to the targeted fishery for the resource, together with expansion in trawling grounds.

Length-weight relationships in S. pharaonis suggest that the estimated " $b$ " values for males, females and for the population were significantly smaller than the isometric value of 3. Analysis of the length-weight relationship of this species using samples collected in beach seines, hook \& line and trawl indicated that the exponent " $b$ " of the length-weight relationship in this species ranges from 2.5 (Silas et al. 1985) to 2.89 (Dunning et al. 1994), displaying negative allometric growth. Negative allometric relationships, where growth in length is significantly higher than a corresponding increase in weight; have been described in many cuttlefish species (Dunning et al. 1994, Reid et al. 2005).

It was observed that females were heavier than males at any given mantle length. Though the females were heavier compared to males throughout the life cycle, the males were found to attain greater ultimate lengths. It appears that the female growth in length declines with maturation and the weight gain during the period is largely attributable to the increase in the weight of the gonad. Yet another possibility of females weighing heavier than males lies in their morphometric difference where the females have a relatively wider posterior mantle than the males, a characteristic that is also reported in other species (for instance in

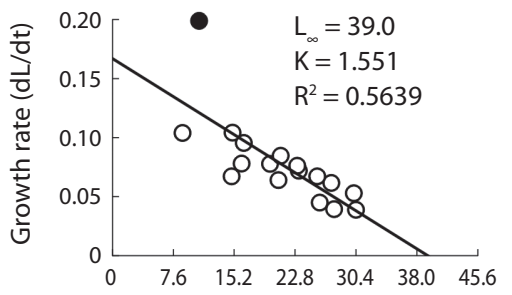

Female: Post-monsoon cohort

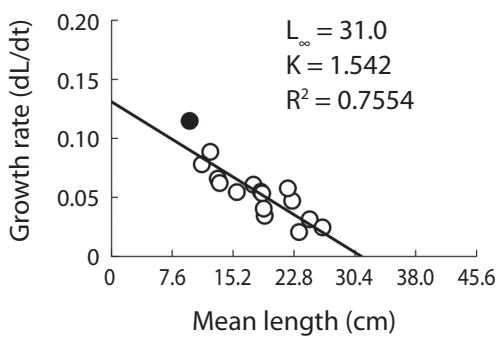

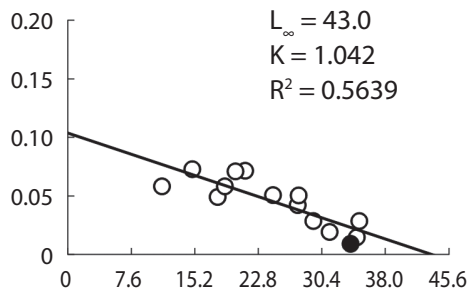

Female: Pre-monsoon cohort



Fig. 7. Growth parameters estimated using Gulland \& Holt plot for S. pharaonis (dark circle denotes points de-selected). 




Fig. 8. Von Bertalanffy growth curve fitted to dorsal mantle growth in S. pharaonis.

Sepia orbignyana) (Bello 1988). Higher ultimate lengths attained by males can also partly explain the different growth patterns for $S$. pharaonis between the sexes. Higher " $b$ " values for female have been reported in many of the previous investigations. Gabr et al. (1999) observed that the sex-wise differences in " $b$ " values for $S$. pharaonis from Suez Canal were not significant. It is highly probable that this observation was because, the length range in the data set used for the Suez Canal study was small $(1-24 \mathrm{~cm})$, while the present study included a larger size range $(4-41 \mathrm{~cm})$. The differences in the ultimate lengths attained by males and females can bring about wider variations in the weight-at-length, particularly in larger size classes.

Age and growth of S. pharaonis have been described only by few investigators in its distributional range. By assigning ages to length frequency modes, Silas et al. (1985) projected a $\mathrm{L}_{\infty}$ for male as $36.5 \mathrm{~cm}$ and as $34.2 \mathrm{~cm}$ for female and worked out a life span of three years with lower $\mathrm{K}$ values. Later, Nair et al. (1993) estimated the $\mathrm{L}_{\infty}$ of $32 \mathrm{~cm}$ for male and $29 \mathrm{~cm}$ for female cuttlefish from the West coast of India (Arabian Sea) with a growth coefficient of less than 1. Similarly, they estimated the $\mathrm{L}_{\infty}$ for cuttlefish from the East coast of India (Bay of Bengal) as $27 \mathrm{~cm}$ for male and
$23 \mathrm{~cm}$ for female with higher $\mathrm{K}$ values. In a recent study, the $\mathrm{L}_{\infty}$ for the $S$. pharaonis population from East coast of India was estimated as $31 \mathrm{~cm}$ (Abdussamad et al. 2004). The estimates obtained by the present study differed from the results of the earlier studies from India, probably because of the absence of older specimens in the former studies, whereas, the current estimates were strongly influenced by the wide length distribution. In 1980s cephalopods were caught as by-catch in shrimp trawlers (Meiyappan \& Mohamed 2003). Therefore, it is likely that exclusion of adult habitats probably resulted in absence of larger specimens in earlier samples. On the other hand, Sanders (1979) while working on trawl samples $S$. pharaonis along Western Arabian Sea found a similar growth trend with a higher $\mathrm{L}_{\infty}$ estimate of $40 \mathrm{~cm}$, for a growth coefficient of one.

The size-at-age estimated for S. pharaonis in the South-West coast of India was $29-31 \mathrm{~cm}$ for males and $24-25 \mathrm{~cm}$ for females in one year. Silas et al. (1985) estimated that S. pharaonis grows to $18.6-19.7 \mathrm{~cm}$ in the first year with longevity of 3years. In Western Arabian Sea, Sanders (1979) described two cohorts based on the discrete spawning season and concluded that $S$. pharaonis can attain large mantle lengths $(>25 \mathrm{~cm})$ in less than a year and survive for two years. Under controlled laboratory conditions $S$. pharaonis has been reported to attain up to $30 \mathrm{~cm}$ in 8.4 months (Minton et al. 2001). Considering the faster growth rate in $S$. pharaonis, modes in the length frequency data in the present study can be considered as comprising distinct age classes. Therefore, the growth curves fitted through these modes can aptly describe the growth of the species and the phi-prime index values were comparable across different geographic locations.

Exploited population of $S$. pharaonis is composed of a wide range of age/size classes so that any effects of fishing are spread across a number of cohorts. Modeled growth parameters revealed that $S$. pharaonis is a fast-growing species. Approximately $65 \%$ (in female) to $70 \%$ (in male) of linear growth to $\mathrm{L}_{\max }$ is accomplished within the first year of the lifespan. The 
growth curve suggests rapid growth rate for $S$. pharaonis up to an age of one year in the case of females and 1.5years for males, after which an asymptote is approached. Along the Indian East coast, $S$. pharaonis exhibited similar patterns in initial growth during the first year of its lifespan (Abdussamad et al. 2004). The differential growth characteristics observed here are comparable to the general pattern for the group, where males tend to grow to a larger mean length-at-age than females of a similar age (Sanders 1979, Minton et al. 2001). The rate of increase in length with age was greater for males than females, evident from three months onwards; corresponding to a mean size of $9 \mathrm{~cm}$. In culture systems, commencement of mating behaviour in $S$. pharaonis was observed from three months of hatching (Anil et al. 2005). Therefore, the differential growth in the females may possibly be related to the erratic growth at the onset of sexual maturity/ development of gonad besides, the transformation from exponential growth (in about 60 days) to linear growth recorded (Minton 2004).

Analysis of length composition in the fishery indicated that the $0+$ year class was well represented in the population, resulting in a left-skewed length frequency distribution. The strong representation of the $0+$ year groups would be expected considering the targeted fishery for the resource. Smaller-sized individuals in the fishery appeared from January/ February onwards due to juveniles remaining in the shallow coastal waters. However, during the monsoon and post-monsoon season (August-December), smaller individuals of this species were not frequent in the fishing grounds, while smaller species (Sepia elliptica) were represented (Silas et al. 1985). Bimodal patterns with a smaller modal length appeared for a short period from January onwards, when adults remained in the fishing ground at the same time when the recruits enter the fishery. Given that the catch rates during JanuaryMarch were very low, it is fair to infer that the major fraction of the cuttlefish, which hatch out from the post-monsoon spawning migrate offshore to spend their early life in deeper waters.
The seasonal fluctuations in catch rates, suggest the migratory nature of $S$. pharaonis between deeper offshore and inshore coastal zones for feeding and spawning in the Eastern Arabian Sea. Shoreward migration is evident from the increase in catch rates/abundance associated with the arrival of $S$. pharaonis by May/June to inshore waters. The migratory life cycle appears to be similar to the group inhabiting the Western Arabian Sea (Sanders 1979) and Hong Kong waters (Reid et al. 2005), undertaking seasonal migrations between the inshore and offshore waters. With the advancement of monsoon, migration of cuttlefish towards the coastal waters and a corresponding increase in the abundance of cuttlefish in the inshore waters of the Eastern Arabian Sea was observed in trawl surveys (Naik \& Tamilarasan 1998). It should be emphasized that the commencement of shoreward migration influences the landings in commercial fishery and the catch rates. The high proportion of fully mature and spawning specimens in the commercial landings suggests that the species undertakes inshore migration for spawning. This is further supported by the presence of egg clusters of $S$. pharaonis found attached to the hard substratum in the inshore rocky area along the SouthWest coast of India (Anil et al. 2005). It follows that the juveniles then migrate offshore where they feed, grow, mature and later return to shallow waters to complete the life cycle. Thus the distribution may be partly determined by physical parameters and partly by prey availability, besides spawning migration.

The relationship between environmental variables and cuttlefish abundance have been widely reported for temperate cephalopods including Sepia officinalis (Dunn 1999, Dennis \& Robin 2001). Demersal surveys in the Eastern Arabian Sea at 50-200m depth zones from $13^{0}$ to $18^{0} \mathrm{~N}$ recorded reduced catch rates for cuttlefish in 100-200m, compared to shallower area with the advancement of monsoon in May, whereas, by August the cuttlefish occurred within the inshore waters (within 50-100 m) (Naik \& Tamilarasan 1998). It appears that the timing of migration corresponds to the seasonal 
semi-annual reversal in current patterns that occur in the Eastern Arabian Sea with the monsoon winds by mid-May (inshore) and by November (offshore).

In January/February, recruitment to the fishery occurs, as evident from increasing proportions of smaller individuals resulting in a reduction in mean size. Major recruitment occurs in May/June, manifested with rapidly increasing catch rates in addition to an increase in the proportion of smaller individuals. Spawning in inshore waters in October/ November (Sasikumar et al. 2006) accounts for the smaller size groups $(4-5 \mathrm{~cm})$ appearing in January/February in commercial landings, comprising the early recruits from the postmonsoon spawning. In February/March, these smaller cuttlefish are observed to attain maturity even at a minimum size of $7 \mathrm{~cm}$ in males and $12 \mathrm{~cm}$ in females (Sasikumar 2011). They form part of the reproductive stock, spawn in inshore waters, and contribute to the premonsoon cohort.

The growth rates of the two sub-annual cohorts described in the present study displayed variability. The curvature parameter $\mathrm{K}$ indicated rapid growth mainly for the postmonsoon cohort in the region. When species undertake seasonal migrations, they are subjected to higher variability in biotic and abiotic factors, influencing the growth patterns of cohorts (Forsythe \& Van Heukelem 1987, Villegas 2001). In temperate waters, several authors have proposed Mesnil's model for cephalopods with late autumn and late summer cohorts, having different growth rates (Mangold 1987). In the study area, shorter daylight and increasing temperature (Krishnakumar \& Bhat 2008), at the time of hatching and recruitment of $S$. pharaonis in post-monsoon periods, induce faster growth and early maturity in the early recruits from the post-monsoon spawning. Pre-monsoon cohort after recruitment in May/June, remains in the inshore waters during monsoon where the growth rate is relatively reduced under the lowered monsoon temperatures. The rapid growth displayed by many cephalopods makes them sensitive to changes in environmental temperatures (Jackson 1994). Similar patterns in population structure comprising of two cohorts have been elucidated based on the maturity, timing of spawning and the distribution of early life stages of $S$. pharaonis in Western Arabian Sea (Sanders 1979, Aoyama \& Nguyen 1989). This variability in growth rates among the cohorts are attributable to minor temperature changes experienced during the early growth phase (Villegas 2001).

\section{ACKNOWLEDGMENTS}

We wish to thank the Director, CMFRI and the Scientist-in-Charge, Research Centre of CMFRI, Mangalore, for facilities and encouragements. Special appreciation is extended to D. Nagaraja and G. Sampathkumar for their technical assistance in sampling.

\section{RESUMEN}

Sepia pharaonis es una importante especie endémica comercial del trópico Indo-Pacífico. A pesar de su valor comercial, hay muy poca información de sus poblaciones naturales disponible. En este estudio se describen aspectos como composición de tallas, relación longitud-peso, tasas de captura, reclutamiento estacional y patrones de crecimiento entre cohortes de la población (Clado C), distribuidos a lo largo del Mar Arábigo del Este (costa Suroeste de India). Se obtuvo la Longitud del Manto Dorsal (LMD) y el peso de las capturas de los arrastres comerciales, de Abril 2002 a Octubre 2006. Los datos fueron analizados mediante FiSAT y von Bertalanffy. Se capturó un total de 12454 sepias, con una longitud entre $4-41 \mathrm{~cm}$. Los patrones de composición de tallas discriminaron dos pulsos en el reclutamiento de la pesquería, perceptibles por una disminución en el tamaño promedio mensual de la población. Los LMD de las dos cohortes estacionales se sometieron a un análisis de progresión modal mediante el método de Bhattacharya para la estimación del crecimiento. La primera cohorte (después de los monzones) mantiene la principal pesquería, se compone de individuos medianos de rápido crecimiento, mientras que el segundo grupo (pre-monzón) está compuesto por individuos de crecimiento lento y de gran tamaño. Se encontraron diferencias en las características de crecimiento entre sexos y la duración de vida útil se estima en menos de 2.3 años para machos y 2.1 años para hembras. Se observó crecimiento alométrico negativo entre el peso (W) y la longitud (L) para machos (W=0.33069. $\mathrm{L}^{2.5389)}$ y hembras $\left(\mathrm{W}=0.32542 . \mathrm{L}^{2.6057}\right)$. Las hembras fueron más pesadas en comparación con los machos en cualquier longitud de manto. La temporada de pesca más importante 
fue de mayo a noviembre, cuando se tuvieron las tasas de captura mensual más altas, de $1.67-13.02 \mathrm{~kg} / \mathrm{h}$ en comparación con $0.03-0.85 \mathrm{~kg} / \mathrm{h}$ entre diciembre y abril. Las tasas de captura estacional indican un ciclo de vida migratorio de $S$. pharaonis entre las zonas marinas y costeras de las áreas someras.

Palabras clave: sepia, Sepia pharaonis, crecimiento, relación longitud-peso, edad, Mar Arábigo del Este.

\section{REFERENCES}

Abdussamad, E.M., M.M. Meiyappan \& K.R. Somayajulu. 2004. Fishery, population characteristics and stock assessment of cuttlefishes, Sepia aculeata and Sepia pharaonis at Kakinada along the East coast of India. Bangladesh J. Fish. Res. 8: 143-150.

Anderson, F.E., T. Valinassab, C.W. Ho, K.S. Mohamed, P.K. Asokan, G.S. Rao, P. Nootmorn, C. Chotiyaputta, M. Dunning \& C.C. Lu. 2007. Phylogeography of the pharaoh cuttle Sepia pharaonis based on partial mitochondrial 16S sequence data. Rev. Fish. Biol. Fisheries 17: 345-352.

Anil, M.K., J. Andrews \& C. Unnikrishnan. 2005. Growth, behavior and mating of pharaoh cuttlefish (Sepia pharaonis Ehrenberg) in captivity. Isr. J. Aquac. Bamidgeh 57: 25-31.

Aoyama, T. \& T. Nguyen. 1989. Stock assessment of cuttlefish off the coast of People's Democratic Republic of Yemen. J. Shimonoseki Univ. Fish. 37: 61-112.

Barord, G.J., K.N. Keister \& P.G. Lee. 2010. Determining the effects of stocking density and temperature on growth and food consumption in the pharaoh cuttlefish, Sepia pharaonis, Ehrenberg 1890. Aquacult. Int. 18: 271-283.

Bello, G. 1988. Length-weight relationship in males and females of Sepia orbignyana and Sepia elegans (Cephalopoda: Sepiidae). Rapp. Comm. Int. Mer. Médit. 31: 254.

Boyle, P.R. 1990. Cephalopod biology in the fisheries context. Fish. Res. 8: 303-321.

Chotiyaputta, C. 1993. Cephalopod resources of Thailand, p. 71-80. In T. Okutani, R.K. O’Dor \& T. Kubodera (eds.). Recent Advances in Cephalopod Fisheries Biology. Tokai University, Tokyo.

Dennis, V. \& J.P. Robin. 2001. Present status of French Atlantic fishery for cuttlefish (Sepia officinalis). Fish. Res. 182: 1-12.

Dineshbabu, A.P., B. Sridhara \& Y. Muniyappa. 2001. New crustacean resources in the trawl fishery off Mangalore coast. Mar. Fish. Infor. Serv. T. \& E. Ser. 170: 3-5.
Dunn, M.R. 1999. Aspects of the stock dynamics and exploitation of cuttlefish, Sepia officinalis (Linnaeus, 1758), in the English Channel. Fish. Res. 40: 277-293.

Dunning, M., S. McKinnon, C. Lu, J. Yeatman \& D. Cameron. 1994. Demersal cephalopods of the Gulf of Carpentaria, Australia. Aust. J. Mar. Freshw. Res. 45: 351-374.

Forsythe, J.M. \& W.F. Van Heukelem. 1987. Cephalopod growth, p. 135-156. In P.R. Boyle (ed.). Cephalopod Life Cycles, Vol II. Academic, London, England.

Gabr, H.R., R.T. Hanlon, S.G. El-Etreby \& M.H. Hanafy. 1999. Reproductive versus somatic tissue growth during the life cycle of the cuttlefish Sepia pharaonis Erenberg, 1831. Fish. Bull. 97: 802-811.

Gayanilo, Jr. F.C., P. Sparre \& D. Pauly. 1995. The FAOICLARM Stock Assessment Tools (FiSAT) User's guide FAO Computerized Information Series (Fisheries) 8 FAO Rome.

Jackson, G.D. 1994. Applications and future potential on statolith increments analysis in squids and sepioids. Can. J. Fish. Aquat. Sci. 51: 2612-2625.

Johannessen, O.M., G. Subharaju \& J. Blindheim. 1981. Seasonal variations of the oceanographic conditions off the southwest cost of India during 1971-75. FiskDir Skr Serie HavUnders 18: 247-261.

Krishnakumar, P.K. \& G.S. Bhat. 2008. Seasonal and interannual variations of oceanographic conditions off Mangalore coast (Karnataka, India) in the Malabar upwelling system during 1995-2004 and their influences on pelagic fishery. Fish. Oceanogr. 17: 45-60.

Madhupratap, M., K.N.V. Nair, T.C. Gopalakrishnan, P. Haridas, K.K.C. Nair, P. Venugopal \& M. Gauns. 2001. Arabian Sea oceanography and fisheries of the west coast of India. Curr. Sci. 81: 355-361.

Mangold, K. 1987. Reproduction, p. 157-200. In P.R. Boyle (ed.). Cephalopod Life Cycles, Vol II, Comparative Reviews. Academic, London, England.

Meiyappan, M.M. \& K.S. Mohamed. 2003. Cephalopods, p. 221-227. In M.M. Joseph \& A.A. Jayaprakash (eds.). Status of Exploited Marine Fishery Resources of India, Central Marine Fisheries Research Institute, Kochi, India.

Minton, J.W., L.S. Walsh, P.G. Lee \& J.W. Forsythe. 2001. First multi-generation culture of the tropical cuttlefish Sepia pharaonis Ehrenberg, 1831. Aquac. Int. 375-392.

Minton, J.W. 2004. The pattern of growth in the early life cycle of individual Sepia pharaonis. Aust. J. Mar. Freshw. Res. 55: 415-422.

Mohamed, K.S. 1996. Estimates of growth, mortality and stock of the Indian squid Loligo duvauceli Orbigny, 
exploited off Mangalore, southwest coast of India. Bull. Mar. Sci. 58: 393-403.

Mohamed, K.S. \& G.S. Rao. 1997. Seasonal growth, stockrecruitment relationship and predictive yield of the Indian squid, Loligo duvauceli (Orbigny) exploited off Karnataka coast. Indian J. Fish. 44: 319-329.

Nabhitabhata, J. 1995. Mass culture of cephalopods in Thailand. World Aquac. 26: 25-29.

Nabhitabhata, J. \& P. Nilaphat. 1999. Life cycle of cultured pharaoh cuttlefish, Sepia pharaonis Ehrenberg, 1831. Spec. Publ. Phuket Mar. Biol. Cent. 19: 25-40.

Naik, S.K. \& P. Tamilarasan. 1998. Demersal fishery resources of monsoon months along central West coast of India. Indian J. Mar. Sci. 27: 449-456.

Nair, K.P., M.M. Meiyappan, P.S. Kuriakose, R. Sarvesan, A.P. Lipton, K.S. Mohamed, P.K. Asokan, M. Joseph \& D. Nagaraja. 1992. Biology of squids caught by squid jigging. Bull. Fish. Surv. India 23: 27-42.

Nair, K.P., M.M. Meiyappan, K.S. Rao, R. Sreenivasan, K. Vidyasagar, K.S. Sundaram, G.S. Rao, A.P. Lipton, P. Natarajan, G. Radhakrishnan, K.S. Mohamed, K.A. Narasimham, K. Balan, V. Kripa \& T.V. Satianandan. 1993. Stock assessment of the pharaoh cuttlefish, Sepia pharaonis. Indian J. Fish. 40: 85-94.

Pauly, D. \& J.L. Munro. 1984. Once more on growth comparison in fish and invertebrates. Fishbyte 2: 21 .

Philip, K.P. \& D.M. Ali. 1989. Population dynamics and stock assessment of the cuttlefish, Sepia pharaonis (Ehrenberg) in Wadge Bank, p 66-75. In Studies of fish stock assessment in Indian waters. Special Publication 2, Fishery Survey of India.

Rao, G.S. 1988. Biology of inshore squid Loligo duvauceli Orbigny with a note on its fishery off Mangalore. Indian J. Fish. 35: 121-130.

Reid, A., P. Jereb \& C.F.E. Roper. 2005. Family Sepiidae, p. 57-152. In P. Jereb \& C.F.E. Roper (eds.). 'Cephalopods of the world An annotated and illustrated catalogue of species known to date Volume 1 Chambered nautiluses and sepioids (Nautilidae, Sepiidae, Sepiolidae, Sepiadariidae, Idiosepiidae and Spirulidae) FAO Species Catalogue for Fishery Purposes 4(1), FAO Rome.

Sanders, M.J. 1979. Preliminary stock assessment for the cuttlefish Sepia pharaonis taken off the coast of the
People's Democratic Republic of Yemen UNDP/ FAO, RAB/77/008/6: 1-56.

Sasikumar, G., P. Rohit, D. Nagaraja Lingappa \& R.A. Naik. 2006. Fish aggregating devices used for cephalopod fishery along the Karnataka coast. Mar. Fish. Infor. Serv. T. \& E. Ser. 189: 9-13.

Sasikumar, G. 2011. Mantle length and maturation in exploited stock of pharaoh cuttlefish Sepia pharaonis along Karnataka coast, p. 68-69. In A. Gopalakrishnan et al. (eds). Renaissance in Fisheries: Outlook and Strategies-Book of Abstracts, $9^{\text {th }}$ Indian Fisheries Forum, Central Marine Fisheries Research Institute, Kochi and Asian Fisheries Society, Indian Branch, 19-23 December 2011, Chennai, India.

Silas, E.G., K.S. Rao, R. Sarvesan, K.P. Nair, K. Vidyasagar, M.M. Meiyappan, Y.A. Sastry \& B.N. Rao. 1985. Some aspects of the biology of cuttlefish, p. 49-70. In E.G. Silas (ed). Cephalopod bionomics, fisheries and resources of the EEZ of India. Bulletin, No 37. Central Marine Fisheries Research Institute, India.

Snedecor, G.W. \& W.G. Cochran. 1967. Statistical methods, Oxford and IBH Publishing Co, New Delhi.

Sokal, R.R. \& F.J. Rohlf. 1995. Biometry. Freeman, New York, USA.

Sparre, P. \& S.C. Venema. 1998. Introduction to tropical fish stock assessment Part 1 Manual (Rev 2) FAO Fisheries Technical Paper 306(1) FAO, Rome.

Srinath, M., S. Kuriakose \& K.G. Mini. 2005. Methodology for estimation of marine fish landings in India. Central Marine Fisheries Research Institute, Spl. Publ. 86: 1-57.

Villegas, P. 2001. Growth, life cycle and fishery biology of Loligo gahi (d'Orbigny, 1835) off the Peruvian coast. Fish. Res. 54: 123-131.

Watanuki, N., E. Rodriguez, R. Blanco \& R. Badan 1993. Introduction of Cuttlefish Basket Trap in Palawan, Philippines, p. 627-631. In T. Okutani, R.K. O’Dor \& T. Kubodera (eds.). Recent Advances in Fisheries Biology. Tokai University, Tokyo.

Zacharia, P.U., K.S. Mohamed, C. Purandhara, H.S. Mahadevaswamy, A.C. Gupta, D. Nagaraja \& U.S. Bhat. 1996. A bio-economic evaluation of the dual fleet trawl fishery of Mangalore and Malpe coast. Mar. Fish. Infor. Serv. T. \& E. Ser. 144: 1-12. 